\title{
USE OF INTRAOPERATORY VANCOMYCIN IN SPINAL SURGERIES
}

\author{
O USO DA VANCOMICINA INTRAOPERATÓRIA EM CIRURGIAS DE COLUNA \\ USO DE LA VANCOMICINA INTRAOPERATORIA EN CIRUGÍAS DE COLUMNA \\ Eduardo Teston Bondan, ${ }^{1}$ Xavier Soler I Graells, ${ }^{1}$ Álynson Larocca Kulcheski, ${ }^{1}$ Pedro Grein del Santoro, ${ }^{1}$ Marcel Luiz Benato ${ }^{1}$ \\ 1. Hospital do Trabalhador, Spine Surgery, Curitiba, PR, Brazil.
}

\begin{abstract}
Objectives: Despite the use of systemic antibiotic prophylaxis, infection is still a challenge for spine surgeons, with high morbidity and mortality, long hospitalization, delayed rehabilitation, and a greater number of interventions. The purpose of this cross-sectional retrospective case-control study was to compare the incidence of postoperative infection in individuals who received a systemic antibiotic as the sole prophylactic method with those who received vancomycin in the operative wound in association with systemic antibiotic prophylaxis in spinal surgery. Methods: We evaluated 2694 medical records of individuals submitted to posterior spinal surgery in the thoracolumbar segment in the period from January 2012 to June 2017, 1360 in the treatment group and 1334 in the control group. Results: Nineteen (1.39\%) of the treatment group progressed with surgical site infection, compared to 42 (3.14\%) of the control group. Conclusions: There was a significant reduction in the postoperative infection rate with the use of vancomycin $(p=0.0379)$. Level of Evidence III; Case-Control Study.
\end{abstract}

Keywords: Vancomycin; Infection; Antibiotic Prophylaxis; Spine.

\section{RESUMO}

Objetivos: Apesar do uso de antibioticoprofilaxia sistêmica, a infecção ainda constitui um desafio para os cirurgiões de coluna, com alta morbimortalidade, longo período de internação, retardo na reabilitação e maior número de intervenções. O propósito deste estudo transversal retrospectivo tipo caso-controle foi comparar a incidência de infecção pós-operatória nos indivíduos que receberam antibiótico sistêmico como único método profilático aos que receberam Vancomicina na ferida operatória em associação com antibiótico sistêmico em cirurgias na coluna vertebral. Métodos: Foram avaliados 2694 prontuários de indivíduos submetidos à cirurgia de coluna por via posterior no segmento toracolombar no período de janeiro de 2012 a Junho de 2017, sendo 1360 no grupo tratamento e 1334 no grupo controle. Resultados: Dezenove (1,39\%) do grupo tratamento evoluíram com infecção do sítio cirúrgico, em comparação com 42 (3.14\%) do grupo controle. Conclusão: Houve redução significativa na taxa de infecção pós-operatória com o uso da Vancomicina ( $p=0,0379)$. Nível de Evidência III; Estudo de Caso-Controle.

Descritores: Vancomicina; Infecção; Antibioticoprofilaxia; Coluna Vertebral.

\section{RESUMEN}

Objetivos: A pesar del uso de profilaxis con antibióticos sistémicos, la infección todavía constituye un desafío para los cirujanos de columna, con alta morbimortalidad, largo período de internación, retraso en la rehabilitación y mayor número de intervenciones. El propósito de este estudio transversal retrospectivo tipo caso-control fue comparar la incidencia de infección postoperatoria en los individuos que recibieron antibiótico sistémico como único método profiláctico a los que recibieron vancomicina en la herida operatoria en asociación con antibiótico sistémico en cirugías de la columna vertebral. Métodos: Se evaluaron 2694 prontuarios de individuos sometidos a cirugía de columna por vía posterior en el segmento toracolumbar en el período de enero de 2012 a junio de 2017, siendo 1360 en el grupo tratamiento y 1334 en el grupo control. Resultados: Diecinueve (1,39\%) del grupo de tratamiento evolucionó con infección del sitio quirúrgico, en comparación con 42 (3,14\%) del grupo control. Conclusiones: Hubo reducción significativa en la tasa de infección postoperatoria con el uso de la vancomicina ( $p=0,0379)$. Nivel de Evidencia III; Estudio de Caso-Control.

Descriptores: Vancomicina; Infección; Profilaxis Antibiótica; Columna Vertebral.

\section{INTRODUCTION}

The use of systemic antibiotics as surgical prophylaxis is already a well-established routine in spine surgeries. Despite this, infection of the surgical site is still a major problem in our environment. ${ }^{1-4}$

The incidence of deep infection in the surgical site decreases with systemic antibiotic prophylaxis, however, according to the literature, infection rates still reach values close to $10 \% .^{5,6}$

The impact of infection in spine surgeries results from the necessity for a long period of hospitalization, as well as from the delay in postoperative rehabilitation. ${ }^{6,7}$
The intraoperative prophylactic use of vancomycin has shown consistent results in recent years, with reduced rates of infection and, therefore, of the morbidities associated with procedures performed on the spine. . $^{8,9}$

The objective of this study was to compare the incidence of postoperative infection in individuals who received systemic antibiotics as the only prophylactic method to those who received vancomycin in the surgical wound in combination with intravenous antibiotic prophylaxis in spine surgeries. 


\section{METHODS}

This was a longitudinal, retrospective, case-control study conducted through the analysis of the medical records of patients who underwent posterior approach surgical treatment of the thoracolumbar spine performed by the spine surgery group of the Hospital do TrabaIhador and the Hospital de Clínicas UFPR (Curitiba, Brazil) during the period from January 2012 to June 2017 . The study was approved by the Institutional Review Board as number 60655416.0.0000.5225. All participants signed the Informed Consent Form.

Included in the study were patients who underwent open posterior approach spine surgery indicated for trauma or degenerative diseases and who progressed with infection of the surgical site.

Excluded from the study were surgeries performed via minimally invasive approach, surgeries to correct scoliosis, revision surgeries, surgeries in segments other than the thoracolumbar segment, anterior or double approach surgeries, individuals who lost the segment following surgical treatment, participants with incomplete medical record data, patients previously treated for spondylodiscitis, and individuals who had already presented either local or distant infection at the time of surgery.

Two homogeneous groups were created according to the type of antibiotic prophylaxis instituted in the surgery. For the Treatment Group, we selected the patients submitted to spine surgery who received intravenous cefazolin 2 grams in the anesthetic induction, combined with vancomycin in powder form for topical use in the surgical wound, which was applied to the entire extension of the wound (subfascial and subcutaneous) just before plane closure, one gram being prescribed for surgeries up to 3 levels. ${ }^{7}$ In surgical procedures involving more than 3 levels, 2 grams of topical vancomycin was used, in accordance with the protocol proposed by O'Neil et al. ${ }^{10}$ The Control Group was comprised of the individuals who received intravenous cefazolin 2 grams in the anesthetic induction as the sole prophylactic method.

We analyzed parameters such as age, sex, number of levels surgically approached, type of germ observed in the cultures, time between the surgery and the diagnosis of postoperative infection, duration of hospitalization, and type of antibiotic prophylaxis instituted.

For the diagnosis of postoperative infection the following clinical parameters were considered: hyperemia in the surgical wound and fever, presence of fistula draining purulent contents, seroma with local phlogistic signs, cerebrospinal fluid fistula associated with phlogistic signs, or pseudoarthrosis associated with any of the clinical signs mentioned. The laboratory parameters of infection considered were elevated leukogram values (with or without deviation), elevation of the erythrocyte sedimentation rate (ERS) and C-reactive protein (CRP), in addition to positive blood cultures or cultures of surgical wound secretions, only the cultures having been included in this analysis. Neither complementary exams nor the management (clinical or surgical) of postoperative infection were analyzed in this study. Similarly, neither surgical time nor intraoperative complications were analyzed.

We analyzed the data assisted by the free Biostat 5.0 software with the application of the Kruskal-Wallis test by mean of the comparison of the groups using by the Student-Newuman-Keuls test, which showed homogeneity between the groups studied. For the analysis of the independent samples, we conducted the t-test, considering a value of $p<0.05$ to be statistically significant.

\section{RESULTS}

Of the thoracolumbar surgical procedures performed at the Hospital do Trabalhador and at the Hospital de Clínicas UFPR from January 2012 to June 2017, 2694 cases met the study inclusion criteria - 1360 for the treatment group and 1334 for the control group. This sample was divided homogeneously and with statistical representativity $(p<0.05)$. Nineteen individuals $(1.39 \%)$ in the treatment group contracted infection of the surgical site as compared to 42 cases $(3.14 \%)$ in the control group $(p=0.037)$, as shown in Figure 1.

\section{Treatment group}

Of the 1360 patients in the treatment group, nineteen had infection at the surgical site (9 men [47.3\%] and 10 women [52.6\%]).
The mean age was 47 years (26 to 70 years). Nine (47.3\%) had undergone the surgical procedure for degenerative disease, while $10(52.6 \%)$ had been operated for fracture (Figure 2).

Nine (47.36\%) were operated at 1 level, 5 (26.31\%) at 2 levels, $3(15.78 \%)$ at 3 levels, and $2(10.52 \%)$ at 4 or more levels. Staphylococcus aureus was identified in 7 cases (37\%), other microorganisms in 6 cases $(31 \%)$, and no organism was identified in the other 6 cases (31\%). The other microorganisms isolated in this group were Pseudomonas aeruginosa (3), Staphylococcus epidermidis (1), Streptococcus mitis (1), and Enterobacter spp. (1). The mean time between surgery and a diagnosis of infection of the surgical wound was 53 days ( 7 to 200 days). The mean hospitalization time was 30 days (10 to 90 days). The symptoms that led to a diagnosis of postoperative infection in this group were hyperemia in the wound or fever in $6(31 \%)$, fistula or purulent secretion draining from the wound in 8 (42\%), cerebrospinal fluid fistula associated with superficial infection in $2(10.5 \%)$, infected pseudoarthrosis in $2(10.5 \%)$, and infected seroma in 1 (5.2\%). Table 1

\section{Control group}

Of the 1334 individuals in the control group, forty-two presented infection at the surgical site, 23 of whom (54.76\%) were men and 19 of whom (45.23\%) were women, with no differences between the groups $(p=0.814)$. The mean age was 50 years (22 to 86 years), with no difference between the groups $(p=0.863)$. In our multivariate analysis comparing the individuals with postoperative infection who were operated for degenerative disease with those with infection following surgeries for trauma, we did not observe any statistical difference between the groups studied in terms of age (degenerative $p=0.203$; trauma $p=0.258$ ) or number of levels (degenerative $p=0.299$; trauma $p=0.157$ ), as can be seen in Figure 3 . Similarly, there was no statistical difference between the groups for

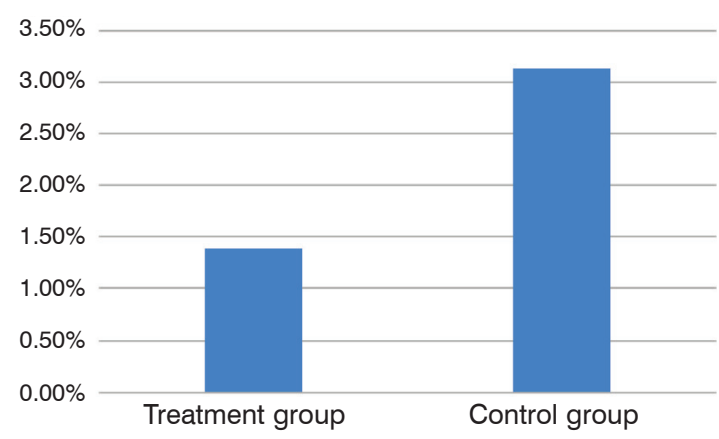

Comparison of the postoperative infection rate (in \%) $p=0.037$

Figure 1. Comparison of the postoperative infection rate (in \%), $p=0.037$

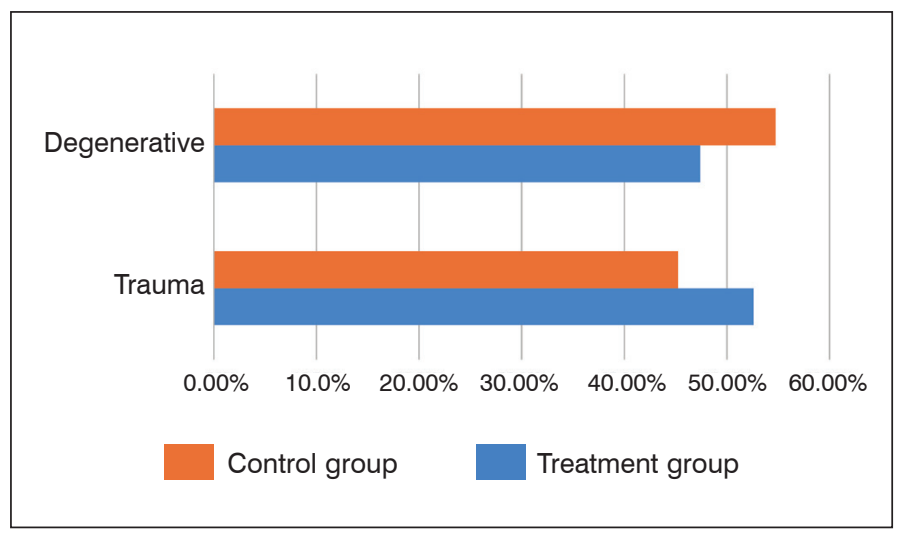

Figure 2. Postoperative infection rate by surgical indication (in \%) $p=0.065$. 
the microbiotic profiles, in terms of postoperative infection in trauma $(p=0.272)$ or in degenerative disease $(p=0.306)$.

Twenty-three (54.7\%) degenerative spinal pathologies were operated and 19 (45.2\%) infections occurred following fixation of spinal fractures. There was a tendency towards significance in the increase of the postoperative infection rate for trauma as compared to that for degenerative pathologies $(p=0.065)$. Twenty-one $(50 \%)$ were operated at 1 level, $11(26 \%)$ at 2 levels, $7(17 \%)$ at 3 levels, and $3(7 \%)$ at 4 or more levels. There was no relationship between the number of levels involves and an increase in the rate of infection $(p=0.396)$. In the control group, 24 (57\%) of the infections were by Staphylococcus aureus, 8 (19\%) by other agents, and $10(23.8 \%)$ had no microorganism identified. The other microorganisms observed in the control group were Escherichia coli (2), Staphylococcus epidermidis (1), Streptococcus

Table 1. Comparison of the Treatment and Control groups.

\begin{tabular}{|c|c|c|c|}
\hline Parameters & Treatment group, $\mathbf{N}$ & Control group, $\mathbf{N}$ & p-value \\
\hline Sex & $10(52.63 \%) \mathrm{F}$ & $23(54.76 \%) \mathrm{M}$ & $p=0.814$ \\
\hline Age & 46.78 (26-70у.) & 50.30 (22-86y.) & $p=0.863$ \\
\hline Type of Surgery & \begin{tabular}{l|l} 
Trauma -10 (52.63\%) & Degenerative - $9(47.36 \%)$ \\
\end{tabular} & Trauma - $19(45.23 \%) \quad$ Degenerative $-23(54.76 \%)$ & $p=0.065$ \\
\hline Levels (in N) & $\begin{array}{l}1-9(47.36 \%) \\
2-5(26.31 \%) \\
3-3(15.78 \%) \\
\geq 4-2(10.52 \%)\end{array}$ & $\begin{array}{c}1-21(50.00 \%) \\
2-11(26.19 \%) \\
3-7(16.66 \%) \\
>4-3(7.14 \%)\end{array}$ & $p=0.396$ \\
\hline Microorganism & $\begin{array}{l}\text { Staphylococcus aureus }-7(36.84 \%) \\
\text { Pseudomonas aeruginosa }-3(15.78 \%) \\
\text { Staphylococcus epidermidis }-1(5.26 \%) \\
\text { Streptococcus mitis }-1(5.26 \%) \\
\text { Enterobacter spp. }-1(5.26 \%) \\
\text { No agent }-6(31.57 \%)\end{array}$ & $\begin{array}{l}\text { Staphylococcus aureus - } 24(57.14 \%) \\
\text { Escherichia coli }-2(4.76 \%) \\
\text { Staphylococcus epidermidis }-1(2.38 \%) \\
\text { Streptococcus epidermidis }-1(2.38 \%) \\
\text { Streptococcus mitis }-1(2.38 \%) \\
\text { Enterococcus fecalis }-1(2.38 \%) \\
\text { Salmonella spp. }-1(2.38 \%) \\
\text { Serratia marcensens }-1(2.38 \%) \\
\text { No agent - } 10(23.80 \%)\end{array}$ & $p=0.254$ \\
\hline Diagnosis time (in days) & $52.84(7-200)$ & $69.26(7-360)$ & $p=0.124$ \\
\hline $\begin{array}{l}\text { Hospitalization time } \\
\text { (in days) }\end{array}$ & $30.47(10-90)$ & $25.76(7-72)$ & $p=0.204$ \\
\hline Symptoms & $\begin{array}{l}\text { Hyperemia + Fever }-6(31.57 \%) \\
\text { Fistula + Purulent contents }-8(42.10 \%) \\
\text { Cerebrospinal fluid fistula + Infection }-2(10.52 \%) \\
\text { Infected seroma }-1(5.26 \%) \\
\text { Infected PSA }-2(10.52 \%)\end{array}$ & $\begin{array}{l}\text { Hyperemia + Fever }-11(26.19 \%) \\
\text { Fistula + Purulent contents }-11(26.19 \%) \\
\text { Cerebrospinal fluid fistula + Infection }-4(9.52 \%) \\
\text { Infected seroma }-6(14.28 \%) \\
\text { Infected PSA }-10(23.80 \%)\end{array}$ & $p=0.252$ \\
\hline Total & 19 & 42 & \\
\hline
\end{tabular}

Source: Electronic medical records - Hospital do Trabalhador and Hospital de Clínicas of UFPR

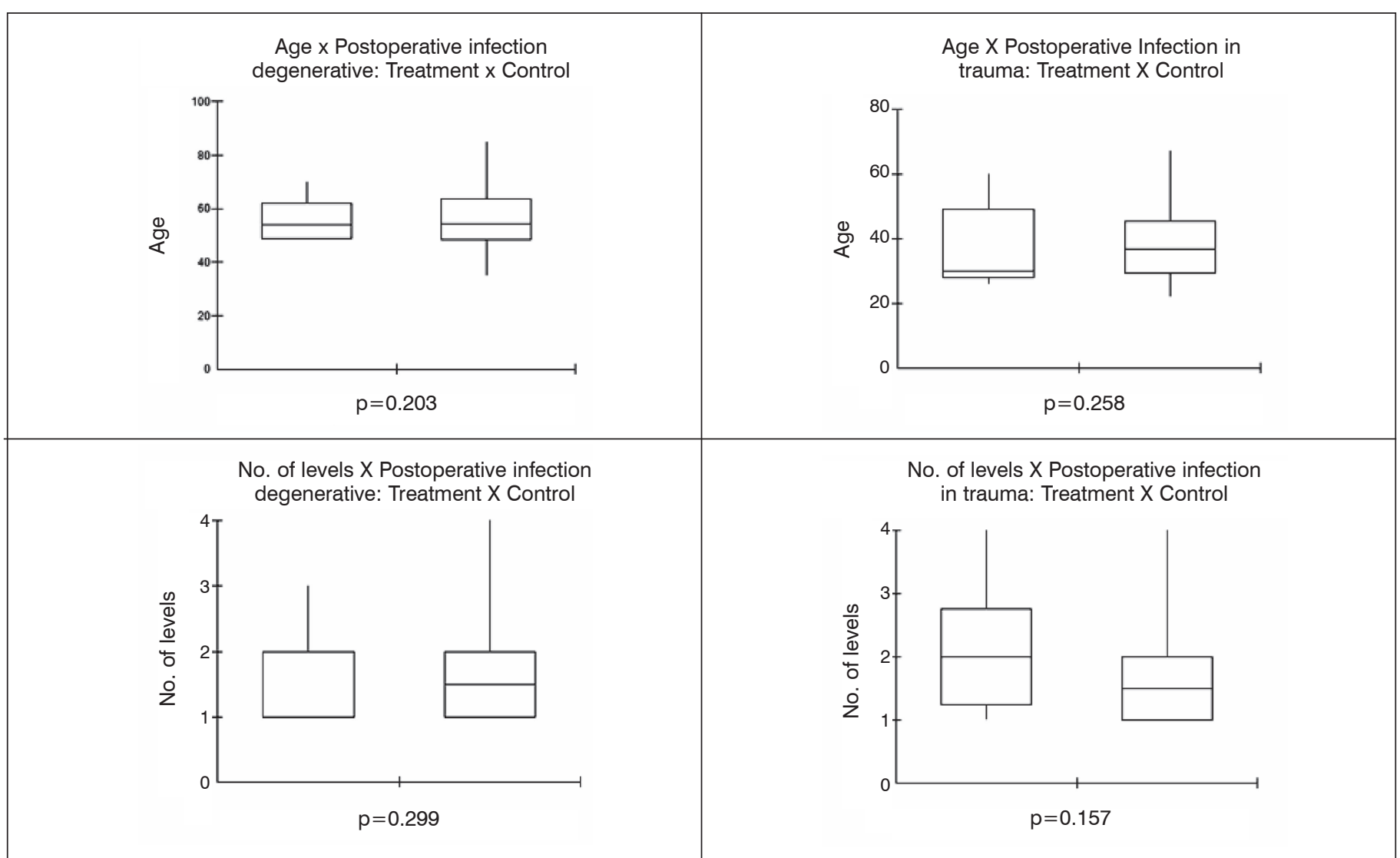

Figure 3. Multivariate analysis of both groups (treatment $x$ control) in relation to postoperative infection of the spine after trauma in comparison to surgery for degenerative disease. Boxplots 1 and 2 do not show any difference associated with the age of the patients ( $p>0.05)$. Boxplots 3 and 4 do not show any difference in relation to the number of levels approached $(p>0.05)$. 
epidermidis (1), Streptococcus mitis (1), Enterococcus fecalis (1), Salmonella spp. (1), and Serratia marcensens (1). There was no difference in the profile of microorganisms isolated after the introduction of topical vancomycin to the surgical wound $(p=0.254)$. The mean time between the surgery and the diagnosis of infection was 69 days (7 to 360 days), with no difference between the groups $(p=0.124)$. The mean hospitalization time was 26 days ( 7 to 72 days), with no difference between the groups $(p=0.204)$. The symptoms that led to the diagnosis of postoperative infection were hyperemia in the wound or fever in 11 cases (26.2\%), fistula or purulent secretion draining from the wound in 11 cases $(26.2 \%)$, cerebrospinal fluid fistula associated with superficial infection in 4 cases $(9.5 \%)$, infected pseudoarthrosis in 10 cases (23.8\%), and infected seroma in 6 cases (14.3\%), with no difference between the groups $(p=0.254)$.

\section{DISCUSSION}

Infections in spine surgeries have an incidence of 0.3 to $20 \%$ in the global literature. ${ }^{10}$ In our case series, the incidence of infection prior to the introduction of vancomycin was $3.14 \%$. Despite the low frequency, the presence of infection in spinal surgeries, besides being devastating, worsens patient satisfaction regarding the surgical procedure and increases the cost of treatment, since it is associated with prolonged hospitalization, as seen in this analysis. ${ }^{10}$

Adverse systemic reactions, such as nephrotoxicity, ototoxicity, and skin rash are common with intravenous use of vancomycin. In contrast, the literature has shown the safety of topical vancomycin in the surgical wound, with rare reports of toxicity. ${ }^{11-13}$

In the cases of spinal surgery for degeneration or trauma that involve up to three levels, the recommended dose of topical vancomycin is $1 \mathrm{gram}$. In approaches of more than three levels, $2 \mathrm{~g}$ of topical vancomycin should be administered. ${ }^{6,7,14}$

The literature points out a prevalence of infection in spinal surgeries for trauma when compared to surgical procedures for degenerative diseases of the spine. ${ }^{9,10}$ However, in our study we observed a tendency towards statistical significance in the increase in the rate of postoperative infection in trauma as compared to that of postoperative infection in degenerative pathologies $(p=0.065)$, as shown in Figure 2 .

Hey et al., ${ }^{11}$ in their study of 389 individuals with postoperative infections in spine surgeries, observed a reduction in the rates of infection from $6.3 \%$ to $0.8 \%(p=0.049)$ after the introduction of vancomycin in the surgical wound as an adjuvant in the antibiotic prophylaxis. Similarly, in our study we observed a significant reduction $(p=0.037)$ in infection rates, from $3.1 \%$ to $1.4 \%$, applying the same prophylactic method.

The literature points out the prevalence of Pseudomonas aeruginosa when topical vancomycin is used, but there are no statistical data in our study to support this datum as significant. ${ }^{12}$ Similarly, in our study this agent was not observed prior to the use of vancomycin and presented a frequency of $15.78 \%$ among the infected postoperative cases that had used the topical antibiotic in the surgical wound. Despite this, the change in the microbiotic profile did not have statistic representability $(p=0.254)$ and Staphylococcus aureus still prevailed, with an incidence ranging from $36.8 \%$ to $57 . \%$. No case of local or systemic toxicity was noted after the introduction of topical vancomycin, corroborating the literature. ${ }^{13,14}$

Despite the homogeneity of the samples, there is a bias in this study in terms of the intra-hospital microbiotic profile, which may have suffered impact changes in our analysis of microbial resistance with the introduction of vancomycin is taken into account.

\section{CONCLUSIONS}

In this study, there was a significant reduction in the indices of infection at the surgical site in those patients who received a combination of local vancomycin and systemic cefazolin as compared to the individuals who received only intravenous antibiotics, with no evidence of local or systemic toxicity associated with the topical use of vancomycin.

All authors declare no potential conflict of interest related to this article.

CONTRIBUTION OF THE AUTHORS: Each author made significant individual contributions to this manuscript. ETB (0000-0002-4096-642X) ${ }^{\star}$, XSG (0000-0002-9636-9165) ${ }^{\star}$, and ALK (0000-0002-0132-6083)* were the main contributors to the writing of the manuscript. ALK, XSG, MLB (0000-00022903-8550* ${ }^{*}$, and PGS (0000-0002-8326-4823)* performed the surgeries. ETB, ALK, and PGS followed-up with the patients and gathered the clinical data. XSG and MLB evaluated the statistical analysis data. ALK, ETB, and XSG conducted the bibliographical research and reviewed the manuscript. ALK and XSG contributed with the intellectual concept of the study. *ORCID (Open Researcher and Contributor ID).

\section{REFERENCES}

1. Beiner JM, Grauer J, Kwon BK, Vaccaro AR. Postoperative wound infections of the spine. Neurosurg Focus. 2003;15(3):E14.

2. Caroom C, Tullar JM, Benton EG. Intrawound Vancomycin Powder Reduces Surgical Site Infections in Posterior Cervical Fusion. Spine (Phila Pa 1976). 2013;38(14):11837.

3. Emohare O, Ledonio CG, Hill BW, Davis RA, Polly DW Jr, Kang MM. Cost savings analysis of intrawound vancomycin powder in posterior spinal surgery. Spine J. 2014; 14(11):2710-5.

4. Evans RP, Clyburn TA, Moucha CS, Prokuski L. Surgical Site Infection Prevention and Control: an emerging paradigm. J Bone Joint Surg Am. 2009;91 Suppl 6:2-9.

5. Ghobrial GM, Thakkar V, Andrews E, Lang M, Chitale A, Oppenlander ME, et al. Intraoperative Vancomycin Use in Spinal Surgery: Single Institution Experience and Microbial Trends. Spine (Phila Pa 1976). 2014;39(7):550-5.

6. Kang DG, Holekamp TF, Wagner SC, Lehman RA Jr. Intrasite vancomycin powder for the prevention of surgical site infection in spine surgery: a systematic literature review. Spine J. 2015;15(4):762-70.

7. Godil SS, Parker SL, O'Neill KR, Devin CJ, McGirt MJ. Comparative effectiveness and cost-benefit analysis of local application of vancomycin powder in posterior spinal fusion for spine trauma. J Neurosurgery Spine. 2013;19(3):331-5.
8. O'Toole JE, Eichholz KM, Fessler RG. Surgical site infection rates after minimally invasive spinal surgery. J Neurosurg Spine. 2009;11(4):471-6.

9. Schroeder JE, Girardi FP, Sandhu H, Weinstein J, Cammisa FP, Sama A. The use of local vancomycin poder in degenerative spine surgery. Eur Spine J. 2016;25(4):102933.

10. O'Neill KR, Smith JG, Abtahi AM, Archer KR, Spengler DM, McGirt MJ, et al. Reduced surgical site infections in patients undergoing posterior spinal stabilization of traumatic injuries using vancomycin powder. Spine J. 2011;11(7):641-6.

11. Hey HW, Thiam DW, Koh ZS, Thambiah JS, Kumar N, Lau LL, et al. Is intraoperative local vancomycin powder the answer to surgical site Infections in spine surgery? Spine (Phila Pa 1976). 2017:42(4):267-74.

12. Zebala LP, Chuntarapas T, Kelly MP, Talcott M, Greco S, Riew KD. Intrawound vancomycin powder eradicates surgical wound contamination: An in vivo rabbit study. $J$ Bone Joint Surg Am. 2014;96(1):46-51.

13. Gans I, Dormans JP, Spiegel DA, Flynn JM, Sankar WN, Campbell RM, et al. Adjunctive vancomycin powder in pediatric spine surgery is Safe. Spine (Phila Pa 1976). 2013;38(19):1703-7.

14. Armaghani SJ, Menge TJ, Lovejoy SA, Mencio GA, Martus JE. Safety of Topical Vancomycin for Pediatric Spinal Deformity. Nontoxic Serum Levels With Supratherapeutic Drain Levels. Spine (Phila Pa 1976). 2014;39(20):1683-7. 